\title{
Assessment of Attitude towards two selected areas of professionalism like honesty and confidentiality among undergraduate medical students of Bangladesh \\ Dr Sadia Jabeen khan, ${ }^{1}$ Professor Dr. Md. Humayun Kabir Talukder, ${ }^{2}$ Dr Kazi Khairul Alam ${ }^{3}$, Dr. Farhana Haque, ${ }^{4}$ Md. Rezaul Karim ${ }^{5}$
}

\begin{abstract}
This descriptive type of cross sectional study was carried out to evaluate the attitude of undergraduate medical students of Bangladesh regarding selected areas of professionalism like honesty and confidentiality. Study period was from July 2017 to June 2018 . Sample size was 837 undergraduates medical students of $1^{\text {st }}, 2^{\text {nd }}, 3^{\text {rd }}$ and 4 th phase of MBBS course from four public and four non government medical colleges of Bangladesh. Convenience sampling technique was adopted in this study. Data collection was done by a modified structured situational judgment test (SJT) self-administered questionnaire which was adopted from general medical council (GMC) and by in-depth interview schedule of students. The data were then compiled and analyzed using SPSS Version 19.Among the study participants, $37.20 \%$ (310) and $62.80 \%$ (537) were males and females respectively. Attitude towards the two most major issues of professionalism were good, mean score were above three in honesty. Mean score was below three in maintaining confidentiality. Result of the present study shows that female students had higher mean professionalism than male. Female students were better than the male students in regards to all two different professional issues and this difference is statistically highly significant $(P=0.00)$. Mean score of professionalism of $1^{\text {st }}$ phase students in all two issues were greater than the respondents of other three phases and this findings was also statistically significant. Medical undergraduates of Bangladesh have a good understanding of acceptable professional honesty but there is scope of improvement. Study recommended that these two issues of professionalism must be taught in the course of undergraduate medical education and should be incorporated in undergraduate medical curriculum with the details of learning outcome what we craving from a registered medical graduate so that learning can be turned into practice.
\end{abstract}

Key words: Assessment, Attitude, Professionalism, Undergraduate medical students

Introduction Medical professionalism is not a new concept and has always been present throughout the history of medicine in the form of a Hippocratic Oath taken by physicians. The key to an effective doctorpatient relationship and a successful diagnosis, treatment, and prevention of diseases is the patient's trust on the physician.

1. Dr Sadia Jabeen Khan, Assistant Professor (Obst. \& Gynae) NICRH, Mohakhali, Dhaka

2. Professor Dr. Md. Humayun Kabir Talukder, Professor, Curriculum Development \& Evaluation, CME, Mohakhali, Dhaka.

3. Dr Kazi Khairul Alam, Assistant Professor, Teaching Methodology, CME

4. Dr. Farhana Haque, Assistant Professor (Obst. \& Gynae) NICRH, Mohakhali, Dhaka

5. Dr. Md. Rezaul Karim, Junior consultant (Cardiology) DGHS, Mohakhali, Dhaka

Address of correspondence: Dr Sadia Jabeen Khan, Asstt. Prof. (Obst. \& Gynae, CC) NICRH, Dhaka Email: sjabeen326@gmail.com

Bangladesh Journal of M edical Education 2020; 11(1); Khan et al., publisher and licensee Association for M edical Education. This is an Open Access article which permits unrestricted non-commercial use, provided the original work is properly cited. 
Significance of fostering professionalism, is not just for registered doctors, but for students too. It underlines the importance of nurturing professionalism from the very beginning of a future doctor's career. Embedding professionalism in the undergraduate medical curriculum, and developing it in medical students who are right at the start of their medical career, is an investment that will pay dividends. It views professional development as a continuum. The professional behaviors developed at an early stage of a doctor's training are likely to be continued throughout their career. ${ }^{2}$ The standards of professional honesty and confidentiality expected of medical students in UK are outlined in 'achieving good medical practice: guidance for medical students'. ${ }^{3}$

Students with well-developed professionalism may be less involved in medical error, and if involved they may have the personal values which can help them to deal with error more honestly and effectively. ${ }^{4}$ Medical students are nascent self-regulating professionals whose statements and actions reflect not just on themselves but also on larger organizations, institutions and ideals. ${ }^{5}$

Medical errors are reported to result in significant morbidity and mortality and are in part related to underdeveloped professionalism. The Quality in Australian Health Care Survey suggested that each year 50,000 Australians suffer permanent disability and 18,000 die at least in-part due to adverse events in the healthcare system. Similar findings have been reported in the USA and Europe. Approximately 35\% of iatrogenic injury relates to failure of professionalism, in contrast to those injuries resulting from inadequacies of knowledge which account for only $1 \%$ of injuries. ${ }^{6}$

Unprofessional and disruptive behavior in medical students is associated with disciplinary action when the students become doctors. $^{7}$

In the last two decades, reports on the incidence of medical error have caused alarm amongst the media and public, and controversy within health systems. Consequently, there has been a call for more effective clinical governance. Though there is no specific survey in Bangladesh in this regard.

Professional development is a continuum starting from undergraduate to clinical practitioner. In our country specific guideline regarding professionalism is not included in undergraduate curriculum like 'A Foundation for the Future: Guidelines for Medical Schools and Medical Students on Undergraduate Professionalism' (Scotland) and Medical student's professional values and fitness to practice. ${ }^{2}$

This study will generate an overview of the undergraduate medical students' attitude regarding professionalism in Bangladesh. It will give us an insight about how far the undergraduate students have learnt from hidden curriculum \& ethics module. The results of this study may help the medical community in its efforts to develop competence in professionalism.

Methods: This was a descriptive type of cross sectional study. The study period was from July 2017 to June 2018. The study was carried out among the students of $11 \mathrm{st}$, 2nd,3rd and 4th phases of MBBS course of 4 government and 4 non-government medical colleges of Bangladesh. Out of 8 medical colleges 5 were within Dhaka and 3 outside Dhaka. The sample size was 837. Medical colleges were selected purposively and convenience sampling technique was adopted for data collection. Foreign students were excluded from the study.

A modified structured situational judgment test (SJT) self-administered questionnaire

Bangladesh Journal of Medical Education 2020; 11(1); Khan et al., publisher and licensee Association for Medical Education. This is an Open Access article which permits unrestricted non-commercial use, provided the original work is properly cited. 
has been used. It was adopted from a survey by General Medical Council. ${ }^{2}$ This type of questionnaire was also used in "Assessment of professionalism in undergraduate medical students". Considering difficulties of English language to comprehend and different cultural context of Bangladesh \& United kingdom (UK) following modification has been done. It has been translated into Bengali language. Some scenario has been changed to fit with our cultural perspective. The study protocol and instruments were approved by the institutional review board (IRB) of Center for Medical Education, Mohakhali, Dhaka.

The researcher introduced herself to the undergraduate students and briefed them about the study and questionnaire. She distributed questionnaires to the undergraduate students after necessary doubts are clarified by the researcher. Questionnaires were distributed to the undergraduate students and they were given 20 minutes to fill up the questionnaire. Data were collected by researcher.

In-depth interview has been taken from 20 students of different phages of different medical colleges to explore the two issues of student's professionalism. Probing has been done to explore attitude of the students.
After collecting responses, data were checked for inconsistent and missing data to reduce errors. Collected data were analyzed and represented through the use of SPSS version 19.0 software. The results of quantitative research were presented in tables and graphs and necessary descriptions were given to explain the views and attitudes of the students about student's professionalism. For each variable frequency distribution was calculated.

Mean were also calculated in some cases. Interpretation of mean score were as follows(arbitrarilyset up by the researcher) 3.5 to $<4=$ Very good standard 3 -to $<3.5=$ good standard. 2.5 to $<3=$ marginal, $<2.5=$ below average.

Results Among the respondent ( $\mathrm{n}=837)$, $62.80 \%$ were female and $37.20 \%$ were male. $25.80 \%$ of respondent were from $1^{\text {st }}$ phase, $25.70 \%$ from $2^{\text {nd }}$ phase, $17.80 \%$ from $3^{\text {rd }}$ phase and $30.70 \%$ from $4^{\text {th }}$ phase. $372(44.5 \%)$ were from public medical colleges among them 222 respondents are from outside Dhaka and 150 are from inside Dhaka and 465 (55.5\%) respondents were from non-government medical colleges among them 143 respondents from outside Dhaka and 322 respondents are from Dhaka Division.

\section{Figure1 .Distribution of respondents by location and type of their medical colleges.}

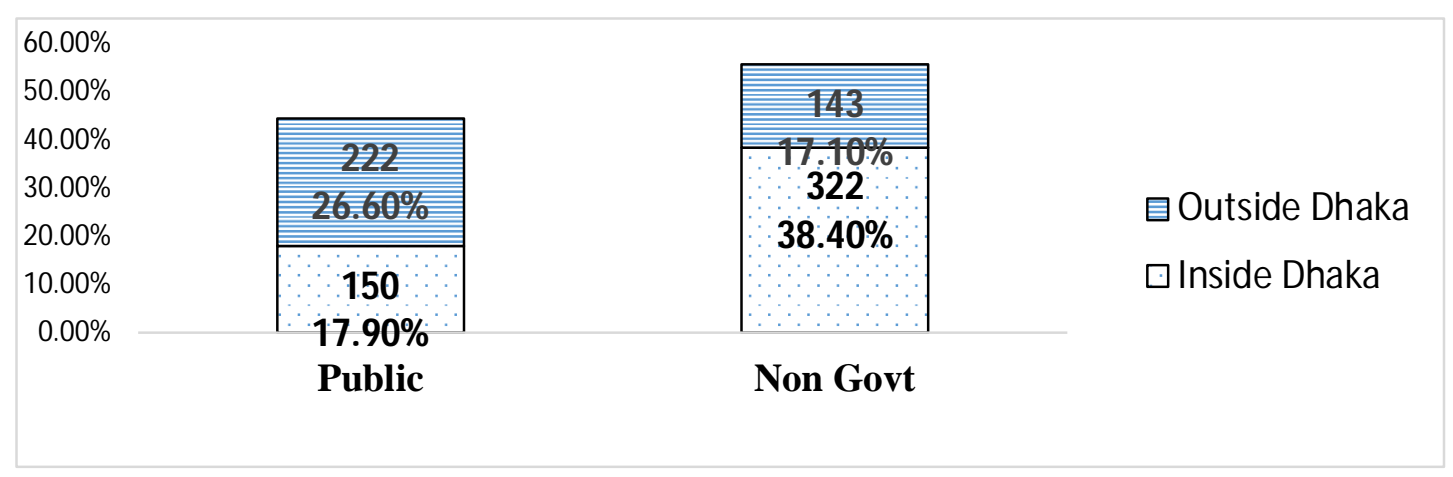

Bangladesh Journal of M edical Education 2020; 11(1); Khan et al., publisher and licensee Association for M edical Education. This is an Open Access article which permits unrestricted non-commercial use, provided the original work is properly cited. 
Table 1 shows out of 837 respondents the overall mean and SD regarding honesty was 3.32 and 0.978. Mean of different issues of professional honesty like proxy signature in the attendance sheet, falsifying teacher's signature in the log book, travelling by bus without paying and finding question before exam date and hiding it all are above 3.

Table 2 shows the distribution of undergraduate students as respondent by their professionalism regarding confidentiality. The overall mean and SD regarding confidentiality were $\mathbf{2 . 9 2 5}$ and when issues arise about disclosing others family matter mean was 3.34 but when question arise about disclosing patients bad habit to others mean was 2.51 .

Table 3 shows that the female students had greater overall positive attitude in honesty and confidentiality than the male students. $(\mathrm{p}=0.000)$.

\section{Figure 2. Distribution of respondents by their gender \&phase}

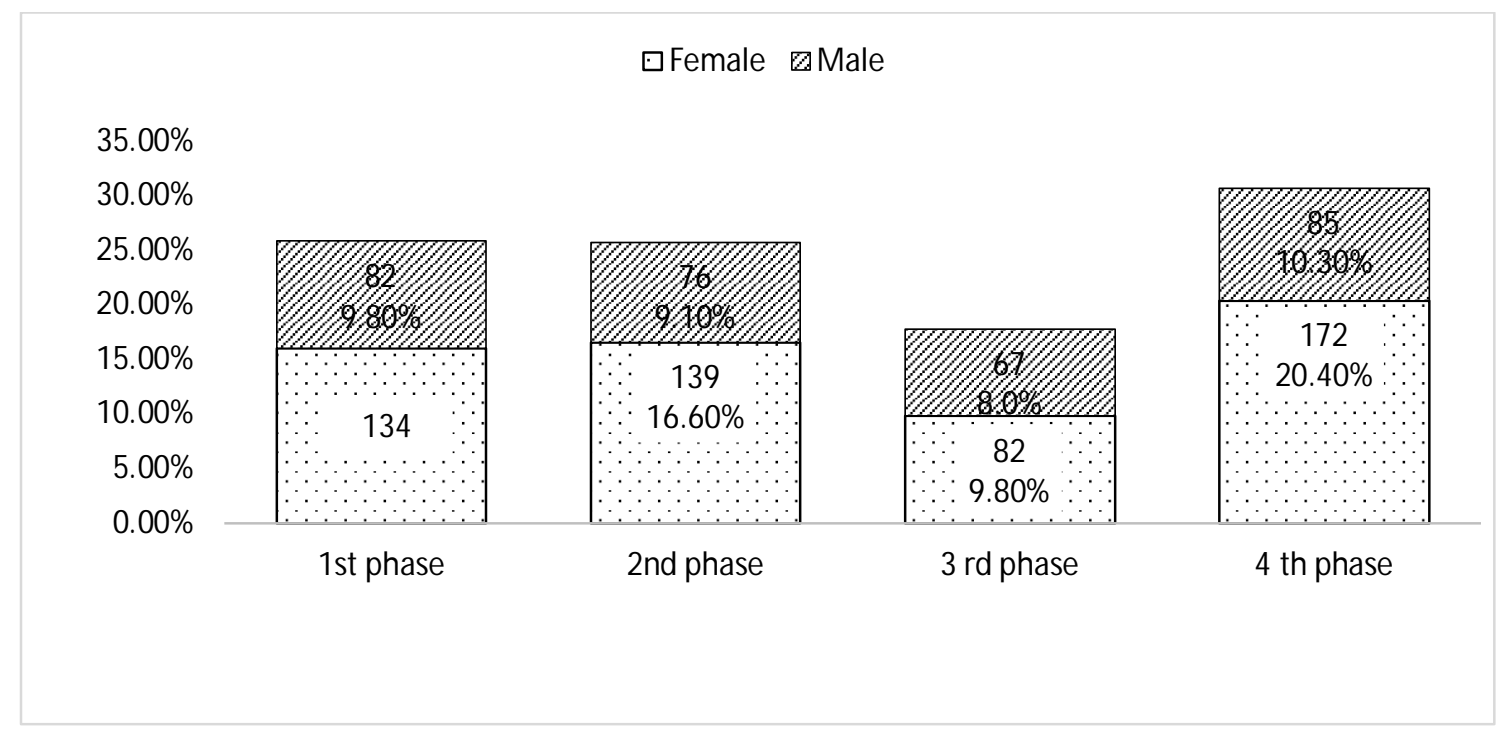

Table 1: Distribution of the students by their professionalism regarding honesty

\begin{tabular}{|c|c|c|c|c|c|}
\hline \multirow{2}{*}{$\begin{array}{l}\text { Issues related to } \\
\text { the professional } \\
\text { honesty }\end{array}$} & \multicolumn{4}{|c|}{ Level of agreement with corresponding scores } & \multirow[t]{2}{*}{$\operatorname{Mean}( \pm$ SD $)$} \\
\hline & $\begin{array}{c}\text { FA=1 } \\
\text { No. }(\%)\end{array}$ & $\begin{array}{c}\text { NA=2 } \\
\text { No. }(\%)\end{array}$ & $\begin{array}{c}\text { NU=3 } \\
\text { No. }(\%)\end{array}$ & $\begin{array}{c}\text { TU=4 } \\
\text { No. }(\%)\end{array}$ & \\
\hline $\begin{array}{l}\text { Proxy signature in } \\
\text { the attendance } \\
\text { sheet in absence } \\
\text { of others }(n=836)\end{array}$ & $108(12.9)$ & $171(20.5)$ & $126(15.1)$ & $431(51.6)$ & $3.05( \pm 1.112)$ \\
\hline $\begin{array}{l}\text { Falsifying } \\
\text { teachers } \\
\text { signature in the } \\
\text { log book } \\
(\mathrm{n}=837)\end{array}$ & $38(4.5)$ & $87(10.4)$ & $107(12.8)$ & $605(72.3)$ & $3.53( \pm .855)$ \\
\hline
\end{tabular}

Bangladesh Journal of M edical Education 2020; 11(1); Khan et al., publisher and licensee Association for M edical Education. This is an Open Access article which permits unrestricted non-commercial use, provided the original work is properly cited. 


\begin{tabular}{lccccc}
\hline $\begin{array}{l}\text { Travelling by bus } \\
\text { without paying } \\
\text { when you are in } \\
\text { short of money } \\
(\mathrm{n}=834)\end{array}$ & $71(8.5)$ & $131(15.7)$ & $196(23.5)$ & $436(52.3)$ & $3.20( \pm .992)$ \\
\hline $\begin{array}{l}\text { Finding question } \\
\text { before exam day }\end{array}$ & $38(4.6)$ & $77(9.2)$ & $123(14.7)$ & $597(71.5)$ & $3.53( \pm .841)$ \\
$\begin{array}{l}\text { and hiding it } \\
(\mathrm{n}=835)\end{array}$ & & & & & \\
\hline Total & & & & & \\
\hline
\end{tabular}

Table 4 Comparing different and overall professionalism among students by their phase of study

\begin{tabular}{llcl}
\hline Professional issues & Gender & Mean $( \pm$ SD $)$ & Statistics \\
\hline \multirow{4}{*}{ Professional honesty } & Phase $(\mathrm{n}=216)$ & $3.4587(.57099)$ & $\mathrm{F}=5.530$ \\
& Phase 2 $(\mathrm{n}=215)$ & $3.3283(.59135)$ & $\mathrm{df}_{\mathrm{B}}=3$ \\
& Phase 3 $(\mathrm{n}=149)$ & $3.2131(.62896)$ & $\mathrm{df}=833$ \\
& Phase 4 $(\mathrm{n}=257)$ & $3.2824(.64779)$ & $\mathrm{P}=0.001$ \\
\hline \multirow{3}{*}{ Maintaining confidentiality } & Phase1 $(\mathrm{n}=213)$ & $3.2091(.59807)$ & $\mathrm{Welch}=14.222$ \\
& Phase 2 $(\mathrm{n}=215)$ & $2.9449(.44256)$ & $\mathrm{df}_{\mathrm{B}}=3$ \\
& Phase 3 $(\mathrm{n}=149)$ & $2.8517(.49900)$ & $\mathrm{df} \mathrm{f}_{\mathrm{W}}=432.798$ \\
& Phase 4 $(\mathrm{n}=255)$ & $2.9584(.58416)$ & $\mathrm{P}=0.000$ \\
\hline
\end{tabular}

Tohlo 2 Cammorina diffarant and avaroll nrofoccionolicm amona macnondants he thair

Table 2: Distribution of the students by their professionalism regarding confidentiality

\begin{tabular}{|c|c|c|c|c|c|}
\hline \multirow{2}{*}{$\begin{array}{l}\text { Issues related to the } \\
\text { professional } \\
\text { confidentiality }\end{array}$} & \multicolumn{4}{|c|}{$\begin{array}{l}\text { Level of agreement with corresponding } \\
\text { scores }\end{array}$} & \multirow[t]{2}{*}{$\operatorname{Mean}( \pm$ SD $)$} \\
\hline & $\begin{array}{c}\text { FA=1 } \\
\text { No. }(\%)\end{array}$ & $\begin{array}{c}\mathrm{NA}=2 \\
\text { No. }(\%)\end{array}$ & $\begin{array}{c}\text { NU }=3 \\
\text { No. }(\%)\end{array}$ & $\begin{array}{c}\text { TU }=4 \\
\text { No. }(\%)\end{array}$ & \\
\hline $\begin{array}{l}\text { Disclosing others } \\
\text { family matter }(\mathrm{n}=827)\end{array}$ & $65(7.9)$ & $95(11.5)$ & 157(19) & $510(61.7)$ & $\begin{array}{c}3.34 \\
( \pm .963)\end{array}$ \\
\hline $\begin{array}{l}\text { Disclosing patients bad } \\
\text { habits }\end{array}$ & $\begin{array}{c}180 \\
(21.8)\end{array}$ & $\begin{array}{c}260 \\
(31.5)\end{array}$ & $\begin{array}{c}171 \\
(20.7)\end{array}$ & $\begin{array}{l}215 \\
(26)\end{array}$ & $\begin{array}{c}2.51 \\
( \pm 1.099)\end{array}$ \\
\hline $\begin{array}{l}\text { Sharing patients picture } \\
\text { in social media without } \\
\text { consent }(n=823)\end{array}$ & $24(2.9)$ & $74(9)$ & $174(21.1)$ & $551(67)$ & $3.52( \pm .778)$ \\
\hline Total & $\begin{array}{c}245 \\
(14.63)\end{array}$ & $\begin{array}{c}355 \\
(21.20)\end{array}$ & $\begin{array}{c}328 \\
(19.6)\end{array}$ & $\begin{array}{c}725 \\
(43.3)\end{array}$ & $\begin{array}{l}2.925 \\
( \pm 0.59)\end{array}$ \\
\hline
\end{tabular}

Bangladesh Journal of M edical Education 2020; 11(1); Khan et al., publisher and licensee Association for M edical Education. This is an Open Access article which permits unrestricted non-commercial use, provided the original work is properly cited. 
Table 4 Showing the comparison of means of different and overall professional issues among the student's by their phase of study. It is observed that there is significant difference of professionalism regarding honesty and confidentiality among the respondents of different phases. It is also observed that though there is no specific pattern of changes of mean score of professionalism among the phases but respondents of 1 st phase always scored highest mean score on all issues.

All students agreed that medical colleges should promote a culture that encourages openness, and honesty at all level. Hardly any student perceived it unethical to proxy in the lecture class. Some of them mentioned "For the sake of friendship it can be done". Drawing practical copy by professional artist by paying money is a routine practice for those who are not good at drawing. When more serious issues came like falsifying teachers signature in item card or practical copy they accepted it as totally unacceptable, though it happened occasionally. They had an opinion that individual's honesty outside the educational environment is the reflection of his/ her previous learning.

Confidentiality is central to the trust between medical professionals and patient and a core element of the doctor/patient relationship.

Undergraduate students had learnt about confidentiality but in their learning environment they saw very little reflection of this vital issue .According to respondent's opinion more or less everyone was casual about the purpose of the disclosure and that they have not bothered for the patient's consent or other legal basis for disclosing patient's information.

Discussion: This descriptive type of cross sectional study was conducted among the 837 undergraduate students of 4 public and 4 non-government medical colleges of Bangladesh. Among the respondents $(\mathrm{n}=837), 44.5 \%$ were from public and $55.5 \%$ from non-government medical colleges respectively (Figure 1). 62.80\% respondent were female and $37.20 \%$ were male. The finding is in accordance with present male and female medical students' ratio in our country. $25.80 \%$ of respondents were from $1^{\text {st }}$ phase, $25.70 \%$ from $2^{\text {nd }}$ phase, $17.80 \%$ from $3^{\text {rd }}$ phase and $30.70 \%$ from $4^{\text {th }}$ phase. (Figure 2).Between December 2014 and January 2015, GMC surveyed medical students in England and Wales and Scotland to get their views on professionalism. That survey guided GMC to review the guidance GMC had given to medical schools and students on professionalism and fitness to practice. $^{2}$

Four questions were placed in the form of modified structured situational judgment test (SJT) to evaluate attitude regarding honesty: 3 for honesty within academic environment and 1for honesty outside the academic environment. The overall mean was 3.32.Around half $(51.6 \%)$ of respondents felt that it was totally unacceptable for a student to ask a friend to sign them in to a lecture if they'd absent. $15.1 \%$ felt it was mostly unacceptable, leaving $12 \%$ who felt the behavior was acceptable and $20.5 \%$ mostly acceptable. This finding is consistent with the survey conveyed by GMC (2015) except $64 \%$ agreed it as totally unacceptable. Similar findings were observed by $61.7 \%$ students. ${ }^{8}$

When students were asked about a more serious example of fraud, falsifying teacher's signature in the log book, a much larger proportion of students considered it to be unacceptable. $72 \%$ of students felt it would be totally unacceptable for a student to forge their supervisor's signature in their log book but surprisingly $4.5 \%$ thought it acceptable.

When students were asked about an act of dishonesty outside their place of study and unrelated to their role as a medical student, about $40 \%$ had chosen mostly unacceptable plus mostly acceptable, again suggesting that in some circumstances this could be

Bangladesh Journal of Medical Education 2020; 11(1); Khan et al., publisher and licensee Association for M edical Education. This is an Open Access article which permits unrestricted non-commercial use, provided the original work is properly cited. 
reasonable.8.5\% of them considered it acceptable which a breach in professionalism. It may also be that students were sympathizing it the student in the scenario who was running low on money at the end of month. In a survey in UK, $16 \%$ of students think it is mostly acceptable for a student who is low on money, to travel on a train without paying their fare. ${ }^{2}$ In this area our students are holding greater financial honesty. Medical students need to behave professionally outside of work and medical school. This means students should avoid doing things that will undermine the trust patients have in doctors and the public has in the medical profession. ${ }^{2}$

Confidentiality is central to trust between doctors and patients. However, confidentiality is not absolute, and appropriate information sharing is essential to the efficient provision of safe, effective care. Students need to be aware that they must never share confidential information about a patient with anyone who is not directly involved in their care without the patient's permission. ${ }^{2}$ Two scenario were given to judge student's professional attitude regarding maintaining confidentiality. Mean and SD regarding confidentiality were 2.925 and 0.59. That means students did not perceived it unprofessional to disclose

were no significant $(P<0.61)$ differences between male and female sexes of the mean scores of professionalism. ${ }^{10}$ Moreover, a similar observation was also noticed in a number of studies where male students had scored lower than their female counterpart. ${ }^{11,12}$ It is not clear why female medical students scored higher. This particular finding can be explained by the fact that females have more responsibility and empathy sense than males. ${ }^{13}$

Result of the present study shows that there is statistically significant difference of professionalism regarding two major issues patient's personal matter. $43.3 \%$ respondent acknowledged it as acceptable to disclose patient's bad habits. Similar finding was revealed by Kumar et al. ${ }^{9}$ They found that $49 \%$ undergraduate students are not confident about maintenance of confidentiality. Female Students are superior in maintaining confidentiality in this study as their mean score (3.07) is greater than male students (2.87).

$67 \%$ perceived it unacceptable to sharing patient's picture in social media without consent. Several countries has prescribed guidance for using social media for medical students. Consider providing specific guidelines on online behavior that is inconsistent with professionalism, for example: Violations of patient confidentiality (recognizing that even when patients are not named, sufficient details may be disclosed to enable identification). Use of offensive or derogatory language. ${ }^{5}$

Result of the present study shows that female students had higher mean professionalism than male (Table 3). Female students were better than the male students in regards to two different professional issues and this difference is statistically significant $(P=0.00)$. This findings is consistent with survey conducted by GMC. ${ }^{2}$ Haque et al revels contrast findings in Malaysia that there

honesty and confidentiality among the respondents of different phases. It is also observed that though there is no specific pattern of changes of mean score of professionalism among the phases but respondents of $1 \mathrm{st}$ phase always scored highest mean score in all issues. $1^{\text {st }}$ phase students are novice in medical society. Their attitude reflect mostly their previous learning. Gradual declining of mean score is the reflection of failure of our educational environment to foster medical professionalism among undergraduates. Haque et al, observed no statistically

Bangladesh Journal of Medical Education 2020; 11(1); Khan et al., publisher and licensee Association for M edical Education. This is an Open Access article which permits unrestricted non-commercial use, provided the original work is properly cited. 
significant difference between phases in Malaysia. ${ }^{10}$

\section{Limitations of the study}

I. Professionalism is difficult issue to be evaluated and needs multiple evaluation tools. Moreover, these tools which researcher had adopted from" Students professionalism our survey of medical students' (2015) by GMC has been modified to fit in our country context.

II. Medical colleges has been selected purposively according to convenience instead of random sampling.

III The real pictures over a period of time might be overlooked as the study was a cross sectional one

\section{Conclusion:}

There is no space for professionalism in latest medical curriculum. Students are not familiar with the term. Despite the fact, undergraduate students have shown quite worthy level of professional attitude in two of the most vital component of medical professionalism honesty and confidentiality.

In this study, student's mean score in professional honesty was above 3 out of 4 . It means that they had good attitude towards this component of professionalism. But it should be improved further to achieve professional excellence. To disclose patient's personal matter is a breach of trust.

In maintaining confidentiality mean score was 2.92 reflecting that students did not perceived it unprofessional to disclose patient's personal matter.

Female respondent acquired higher mean score. These differences were statistically significant. It reflects that female undergraduate medical students had grater overall positive attitude in professionalism than the male students. Teaching professionalism should be targeted to various professional issues. Educational environment should be tailored for constructing professionalism in future doctors so that practicing professional issues can be turned into routine.

It can be concluded that educational environment of undergraduate medical institutes of Bangladesh should be improved further for nurturing professionalism in future doctors.

3. Medical Council, (2014). A Foundation for the Future: Guideline for Medical Schools and Medical Students on Undergraduate Professionalism. Retrived on august 2017 from http://www.medicalcouncil.ie/news\&pu blications.

4. O'Sullivan AJ, Toohey SM, (2008). Assessment of professionalism in undergraduate medical students. Medical Teachers, vol 30: pp.280-286.

5. Ian Brasg ( 2013). Guide to Medical Professionalism: Recommendations for Social Media. CFMS.

Bangladesh Journal of Medical Education 2020; 11(1); Khan et al., publisher and licensee Association for M edical Education. This is an Open Access article which permits unrestricted non-commercial use, provided the original work is properly cited. 
6. Wilson RM, Harrison BT, Gibberd RW, Hamilton JD, (1999). An analysis of the causes of adverse events from the Quality in Australian Health Care Study. Med J.Aust, vol 170: pp.411-414.

7. Papadakis MA, Hodgson CS, Teherani A, Kohatsu N. (2004). Unprofessional behaviour in medical school is associated with subsequent disciplinary action by a State Medical Board. Acad Med,vol 79: pp. 244-249.

8. Gazi S( 2016). Academic honesty among students of selected dental colleges of Bangladesh: A thesis of Centre for Medical Education, Dhaka, Bangladesh.

9. Kumar AP, Scott JX, Rajendiran, Vijayaraghavan PV,(2015). A study on need assessment for curriculum on Professionalism among undergraduate medical students. IOSR Journal of Dental and Medical Sciences (IOSRJDMS) e-ISSN: 2279-0853, p-ISSN: 2279-0861. Volume 14, Issue 10, PP 4852. www.iosrjournals.org.

10. Haque M, Zulkifli Z, Haque SZ, Kamal ZM, Salam A, Bhagat V, Ghazi A, (2016). Professionalism perspective among medical students of a novel medical graduate school in Malaysia. Advances in Medical Education and Practice, vol 7: pp, 407-422.

11. Salam A, Haque M, Islam MZ, (2013). Comparative study of professionalism of future medical professionals among three private medical colleges in Bangladesh.
Asian J Pharm Clin Res, vol 6(3), pp.170-179.

12. Salam A, Song CO, Mazlan NF, Hassin H, Lee LS, Abdullah MH, (2012). Professionalism of future medical professionals in Universiti Kebangsaan Malaysia (UKM) Medical Centre. Int Med J. Vol 19(3), pp. 224-228.

13. Sabbatini RME, (1997). Are There Differences between the Brains of Males and Females? Mind and Behavior; 1997. Available from: http://www. cerebromente.org. br $/ \mathrm{n} 11 /$ mente/eisntein/ cerebro-homens.html. Accessed April 14, 2016.

Bangladesh Journal of Medical Education 2020; 11(1); Khan et al., publisher and licensee Association for Medical Education. This is an Open Access article which permits unrestricted non-commercial use, provided the original work is properly cited. 